\title{
Analisis Pendapatan Petani Lada Di Desa Sanglepongan Kecamatan Curio Kabupaten Enrekang
}

\author{
Income Analysis of Pepper Farmers in Sanglepongan Village Curio District, Enrekang \\ District
}

\author{
Nur Haini ${ }^{*}$, Irmayani $^{1}$, Yusriadi ${ }^{1}$
}

*E-mail: nurhainiaini996@ gmail.com

${ }^{1}$ Program Studi Agribisnis, Fak. Pertanian, Peternakan dan Perikanan, Universitas Muhammadiyah Parepare

Diterima: 01 Mei 2021 / Disetujui: 02 Agustus 2021

\begin{abstract}
ABSTRAK
Penelitian ini bertujuan untuk menentukan tingkat pendapatan dan menguji kelayakan usaha tani Lada Didesa Sanglepongan Kecamatan Curio Kabupaten Enrekang. Metode penelitian yang digunakan adalah metode survey yang bertujuan untuk mendapatkan gambaran yang mewakili suatu daerah dengan benar, dan untuk menjangkau fakta yang terjadi di lapangan melalui kunjungan dan wawancara langsung, sehingga diperoleh gambaran secara keseluruhan mengenai pendapatan ekonomi petani lada Desa Sanglepongan Kecamatan Curio Kabupaten Enrekang berdasarkan berdasarkan data yang diperoleh dari rumah tangga petani..hasil penelitian menunjukkan Total pendapatan lada di daerah sanglepongan adalah Rp149.444.700/produksi. pendapatan petani cukup besar untuk digunakan menutupi kegutuhan hidup dan menunjang keuangan rumah tangga petani dikala tepuruknya harga komoditi pertanian di desa sanglepongan kecamatan Curio Kabupaten Enrekang.Nilai benefit cost ratio (B/C-ratio) adalah sebesar 2,72 menunjukkan bahwa B/C >1 berarti usaha layak untuk dijalankan. Atau denga kata lain pendapatan lebih besar dari total biaya yang dikeluarkan maka usaha ladadi desa sanglepongan di Kecamatan Curio Kabupaten Enekang layak untuk di jalankan
\end{abstract}

Kata Kunci: Pendapatan, Usaha Tani, Lada

\begin{abstract}
This study aims to determine the level of income and test the feasibility of farming in the Village of Sanglepongan, Curio District, Enrekang Regency.The research method used is a survey method that aims to get a picture that represents an area correctly, and to reach the facts that occur in the field through visits and interviews. Directly, in order to obtain an overall picture of the economic income of pepper farmers in sanglepongan village, curio district, enrekang district based on data obtained from farmer households. The results showed that the total income of pepper in the sanglepongan area was Rp.149,444,700 / production. Farmer's income is large enough to be used to cover the necessities of life and support farmer household finances when agricultural commodity prices fall in the Sanglepongan village, Curio district, Enrekang Regency. The value of the benefit cost ratio (B / $C$-ratio) is 2.72 indicating that $B / C>1$ means the business is feasible to run. Or in other words, the income is greater than the total costs incurred for ladadi business in the village of Sanglepongan in Curio Subdistrict, Enekang Regency, which is feasible to run.
\end{abstract}

Keywords: Income, Farming Business, Pepper

(a) (1) This work is licensed under Creative Commons Attribution License 4.0 CC-BY International license

\section{A. PENDAHULUAN}

Usaha tani lada Dikabupaten

Enrekang merupakan salah satu jenis lada yang sudah dikenal dari sejak dulu karena

hasil produksinya menjadi salah satu penyumbang terbesar lada Disulawesi 
selatan. Lada yang terdapat di Enrekang saat ini masih di budidayakan oleh petani karna hasil yang dapat menguntungkan bagi petani, masyarakat

Kabupaten Enrekang memiliki sumber daya alam yang sangat potensial untuk pengembangan tanaman lada, kemudian hal ini dimanfaatkan sebagai bahan rempah-rempah, DiKecamatan Curio Desa Sanglepongan saat ini menjadi salah satu daerah penghasil lada yang cukup potensial untuk pengembangan produksi komoditas lada.

Tabel 1. Luas Lahan Dan Produksi Lada Kabupaten Enrekang.

\begin{tabular}{crr}
\hline Tahun & \multicolumn{1}{c}{$\begin{array}{c}\text { Luas Lahan } \\
\text { (Ha) }\end{array}$} & \multicolumn{1}{c}{$\begin{array}{c}\text { Produksi } \\
\text { (Ton) }\end{array}$} \\
\hline 2015 & $2.710,5$ & 935,65 \\
2016 & $2.650,8$ & 970,93 \\
2017 & 2.798 & $1.048,81$ \\
2018 & 2.872 & 1.107 .68 \\
2019 & 2.946 & $1.165,55$ \\
\hline Sumber :Kantor Dinas Pertanian Enrekang, 2018
\end{tabular}

Pada tahun 2015 luas lahan mencapai $2.710,5$ dan produksinya 935,65 ton, pada tahun 2016 luas lahannya menurun tetapi produksinya meningkat dan tahun 2017 hingga 2019 selalu mengalami kenaikan hingga mencapai luas lahan $2.946 \mathrm{Ha}$ dan produksinya $1.166,55$ ton. Ini menunjukkan produksi lada di Kabupaten Enrekang meningkat dan harga yang semakin turun.
Dalam kegiatan usahatani ada sejumlah faktor produksi yang harus dikeluarkan yang mana harga dari faktor produksi tersebut seringkali tidak stabil karena dipengaruhi oleh nilai rupiah dan tingkat inflasi.Selain itu kondisi alam yang tidak bersahabat seperti hujan yang terus-menerus dapat berdampak pada kualitas dan kuantitas produk juga dapat mempengaruhi jumlah produksi dan penurunan harga jual produk itu sendiri.Oleh karena itu petani harus siap siaga dalam menghadapi jika terjadi kenaikan sejumlah biaya produksi, penurunan jumlah produksi, bahkan penurunan harga produk, agar kegiatan usahatani masih dapat terus bertahan dalam jangka panjang.

Perbedaan pendapatan petani lada sangat bervariasi. Ini disebabkan perbedaan penggunaan berbagai faktorfaktor produksi yang dilakukan petani di desa Sanglepongan, Besar kecilnya pendapatan yang diperoleh petani sangat mempengaruhimotivasi petani itu sendiri dalam melakukan usahatani.Semakin besar pendapatanyang diperoleh petani maka semakin giat dan bersemangat petani tersebutmelakukan usahataninya. Begitu juga sebaliknya.kebutuhan pasar yang sangatmeningkat akan permintaan lada ini. Dengan harga lada yangtinggi 
secara otomatis pendapatan petani juga bertambah disamping pendapatan sampingan lainnya.

\section{B. METODE PENELITIAN}

\section{Tempat Dan Waktu}

Penelitian ini di laksanakan selama satu bulan yang bertempat Di Desa Sanglepongan Kecamatan Curio Kabupaten Enrekang. terpilihnya Desa Sanglepongan Kecamatan Curio Kabupaten Enrekang sebagai lokasi penelitian karena sebagian besar mata pencaharian masyarakat di Desa Sanglepongan Kecamatan Curio Kabupaten Enrekang.

\section{Populasi Dan Sampel}

Populasi dalam penelitian ini yaitu semua petani lada di Desa Sanglepongan Kecamtan Curio Kabupaten Enrekang sebanyak 165 orang adapun cara penentuan sampel yaitu dengan rumus Arikunto (2002) apabila jumlah populasi $<100$ maka jumlah sampel sama dengan jumlah populasi. Jika jumlah populasi>100 maka sampeldapat di ambil sebanyak $10-15 \%$.sehingga sampel dalam penelitian ini sebanyak 25 orang ( $15 \%$ dari 165).

\section{Teknik Pengumpulan Data}

Teknik pengumpulan data yang di gunakan sebagai berikut: a. Observasi merupakan teknik pengumpulan data yang digunakan dengan mengambil secara langsung kegiatan oleh objek peneliti.

b. Wawancara merupakan teknik pengumpulan data yang langsung dalam bentuk tanya jawab dengan responden

c. Quisioner yaitu pertanyaan tertulis dengan diajukan kepada responden dalam menggunakan quisioner, maka peneliti akan banyak mendapatkan data secara factual.

\section{Analisis Data}

Adapun metode yang digunakan dalam analisis petani lada berdasarkan Soekartawi (1995), bahwa total biaya adalah penjumlahan biaya variabel dengan biaya tetap secara matematis dapat dituliskan sebagai berikut:

$$
\mathrm{Tc}=\mathrm{FC}+\mathrm{VC}
$$

Keterangan:

TC = Total Cost (Total biaya dari usaha tani lada $\mathrm{Rp})$

$\mathrm{FC}=$ Fixed Cost $($ Total biaya dri usaha tani lada $\mathrm{Rp})$

$\mathrm{VC}=$ Variabel Coat $($ Total biaya variabel dari usaha tani lada Rp)

Soekartawi (2006), menyatakan bahwa penerimaan usahatani adalah perkalian antara produksi dengan harga jual, biaya usahatani adalah semua pengeluaran yang dipergunakan dalam suatu usahatani, sedangkan pendapatan usahatani adalah selisih antara 
penerimaan dan pengeluaran. Pernyataan ini secara matematis dapat dituliskan sebagai berikut:

$$
\mathrm{TR}=\mathrm{Q} \cdot \mathrm{P}
$$

Di mana:

$\mathrm{TR}($ Total Revenue $)=$ penerimaan total petani (Rp)

$\mathrm{Q}$ (quantity) $=$ jumlah produk yang di hasilkan (Kg, Ton)

$\mathrm{P}$ price $=$ harga jual produk yang di hasilkan ( $\mathrm{Rp} / \mathrm{Kg}, \mathrm{Rp} / \mathrm{Ton})$

Soekartawi (1995) menyatakan pendapatan usahatani adalah selisih antara penerimaan (TR) dan semua biaya (TC), dimana penerimaan usahatani adalah perkalian antara produksi dan harga jual, sedangkan biaya adalah semua pengeluaran yang digunakan dalam suatu usahatani. Jadi rumus pendapatan dapat dituliskan sebagai berikut:

$$
\Pi=\mathrm{TR}-\mathrm{TC}
$$

Keterangan:

$\pi=$ Pendapatan petani lada $(\mathrm{Rp})$

TR Total Revenue $=$ penerimaan petani lada $(\mathrm{Rp})$

TC Total Cost = total biaya produksi lada (Rp)

Untuk mengetahui kelayakan usaha tani lada maka digunakan model analisis B/C ratio menurut Soekartawi (2003), Benefit cost Ratio juga dapat dihitung dengan membandingkan keuntungan atau pendapatan bersih usaha tani degan total biaya produksi usaha tani.pernyataan tersebut dapat dituluskan dengan rumus sebagai berikut:

$$
\mathrm{B} / \mathrm{C} \text { Rasio }=\mathrm{TR} / \mathrm{TC}
$$

$\mathrm{B} / \mathrm{C}$ Rasio = Benevit cost ratio $\pi=$ Pendapatan petani lada (Rp)

$\mathrm{TC}=$ Total biaya produksi

Kriteria yang di gunakan dalam penentuan efesiensi usaha adalah:

a. $\mathrm{B} / \mathrm{C}>1$ berarti usaha layak untuk dijalankan

b. $\mathrm{B} / \mathrm{C}=1$ berarti usaha yang di jalankan mencapai titik impas

c. $\mathrm{B} / \mathrm{C}<1$ berarti usaha tidak layak untuk di jalankan

\section{HASIL DAN PEMBAHASAN}

\section{Tingkat Pendapatan Petani Lada}

Penelitian ini akan menhitung berapa besar pendapatan petani lada dalam satu panen, ada beberapa biaya yang perlu diperhatikan dalam suatu usaha tani, yaitu biaya tetap, biaya variable, biaya tenaga kerja. Untuk lebih jelasnya maka akan dideskripsikan sebagai berikut:

\section{a. Biaya Variabel}

Biaya variabel (variabel cost, disingkat VC) adalah biaya yang jumlahnya berubah-ubah sesuai dengan (tergantung dari) besar kecilnya jumlah produksi. Misalnya biaya bahan-bahan, upah buruh harian (Gilarso 1993). Di sisi lain biaya tidak tetap atau biaya variabel biasanya di definisikan sebagai biaya yang besar kecilnya dipengaruhi oleh produksi yang di peroleh. Yang termasuk 
dalam biaya variabel meliputi benih, pupuk, obat-obatan, tenaga kerja.Disebut pula biaya operasi, artinya manajer selalu mengatur, mengeluarkan sepanjang waktu produksi.Biaya ini selalu berubah tergantung kepada besar kecilnya produksi.

Adapun yang termasuk biaya ini adalah, biaya pembelian bibit, upah tenaga kerja, obat-obatan, bahan bakar dan lain-lainya.biaya variabel kira-kira 90-95\% dari total biaya. Biaya lain-lainya pada umumnya masuk biaya variabel karena besar kecilnya berhubungan langsung dengan besarnya produksi, misalnya pengeluaran-pengeluaran untuk bibit, biaya persiapan dan pengolahan tanah ( mubyarto, 1994)

Tabel 2. Total Biaya Variabel Yang Digunakan Oleh Responden Usaha Tani Lada

\begin{tabular}{|c|c|c|c|c|}
\hline No & Jenis Biaya Variabel & Jumlah & \multicolumn{2}{|c|}{ Nilai (Rp) } \\
\hline 1 & Benih: & 12380 Benih & $\mathrm{Rp}$ & 12.380 .000 \\
\hline \multirow[t]{4}{*}{2} & Pupuk: & & & \\
\hline & Urea & 86 Zak & $\mathrm{Rp}$ & 10.320 .000 \\
\hline & SP36 & $48 \mathrm{Zak}$ & $\mathrm{Rp}$ & 6.720 .000 \\
\hline & $\mathrm{ZA}$ & $70 \mathrm{Zak}$ & $\mathrm{Rp}$ & 8.750 .000 \\
\hline \multirow[t]{3}{*}{3} & Obat-obatan: & & & \\
\hline & Supremo & 55 Botol & $\mathrm{Rp}$ & 3.988 .000 \\
\hline & Nugor & 30 Botol & $\mathrm{Rp}$ & 2.239 .000 \\
\hline \multirow[t]{4}{*}{4} & Tenaga kerja : & & & \\
\hline & Panen & 44 orang & $\mathrm{Rp}$ & 4.400 .000 \\
\hline & $\begin{array}{r}\text { Pengangkutan } \\
\end{array}$ & 31 orang & $\mathrm{Rp}$ & 620.000 \\
\hline & Total Biaya Variabel & & $\mathbf{R p}$ & 49.417.000 \\
\hline
\end{tabular}

Tabel 2 menunjukkan bahwa jenis biaya tidak tetap ada 4 macam yaitu: biaya benih yang dikeluarkan sebesar Rp12.380.000 per produksi, biaya pupuk sebesar Rp25.790.000 per produksi, biaya obat-obatan sebesar Rp6.227.000 per produksi dan biaya tenaga kerja sebesar Rp5.020.000 per produksi . jadi dalam satu kali produksi yang paling tertinggi adalah biaya pupuk yakni sebesar Rp 25.790.000 dan yang paling terendah adalah biaya tenaga kerja sebesar Rp5.020.000 maka total biaya tidak tetap yang dikeluarkan petani responden dalam melakukan kegiatan produksi adalah $\mathrm{Rp}$ 49.417.000 per produksi.

Hal ini sesuai pendapat Suratya (2006), yang menjelaskan bahwa biaya tidak tetap adalah biaya yang digunakan pada setiap musim tanam dengan jumlah dan besarnya tergantung skala produksi.

Mubyarto (1994) menyatakan biaya tidak tetap disebut pula biaya oprasi, artinya manejer selalu mengatur, mengeluarkan sepanjang waktu produksi. Biaya ini selalu berubah tergantung kepada besar kecilnya produksi.Yang termasuk biaya ini adalah biaya 
pembelian bibit, upah tenaga kerja, obatobatan, bahan bakar dan lainlainnya.Biaya variabel kira-kira 90-95\% dari total biaya.Biaya lain-lainnya pada umumnya masuk biaya variabel karna besar kecilnya berhubungan dengan besarnya produksi, misalnya pengeluaran umtuk bibit, biaya persiapan dan pengolaha tanah.

Biaya variabel (variabel cost, disingkat VC) ialah biaya yang jumlahnya berubah-ubah sesuai dengan (tergantung dari) besar kecilnya jumlah produksi. Misalnya biaya bahan-bahan, upah buruh harian (Gilarso 1993). Di sisi lain biaya tidak tetap atau biaya variabel biasanya di definisikan sebagai biaya yang besar kecilnya dipengaruhi oleh produksi yang di peroleh. Contohnya biaya untuk sarana produksi. Kalau menginginkan produksi yang tinggi, maka tenaga kerja perlu di tambah, pupuk juga perlu dan sebaiknya, sehingga biaya ini sifatnya berubah-ubah tergantung dari besar kecilnya produksi yang di inginkan.

\section{b. Biaya Tetap}

Biaya tetap merupakan biaya yang dikeluarkan dalam besaran yang tetap atau stabil. Biaya tetap ini keberadaannya tidak dipengaruhi oleh adanya perubahan jumlah atau aktivitas produksi pada tingkat tertentu. Jadi, biaya ini lebih dipengaruhi oleh sebuah kondisi dalam jangka panjang seperti pajak bumi dan bangunan, serta biaya penyusutan

Penyusutan dan nilai sisa adalah pengurangan nilai suatu barang karena adanya pemakaian selama dalam suatu kurung waktu tertentu, sedangkan nilai sisa (savage value) adalah sisa daripada “ capital assets" yang tidak terpakai habis selama umur proyek usaha budidaya (Irmayani 2014).

Jenis alat yang digunakan dalam usaha tani lada meliputi panci, saringan besi, baskom saringan,timbah, baskom besar, karpet gabah dan karung.setelah beberapa jenis biaya di analisis makadapat dihitung seluruh biaya yang diekeluarkan petani lada dapat dilihat pada Tabel 3

Tabel 3. Total Biaya Tetap Yang Digunakan Oleh Responden Usaha Tani Lada

\begin{tabular}{clc}
\hline No & Jenis Biaya Tetap & Nilai $(\mathrm{Rp})$ \\
\hline 1 & Pajak & Rp 1.030 .000 \\
2 & penyusutan peralatan & Rp4.308.300 \\
\hline \multicolumn{2}{c}{ Jumlah } & Rp5.338.300
\end{tabular}

Tabel 3 menunjukkan bahwa ada 2 biaya tetap yang dikeluarkan oleh setiap responden adalah pajak dan penyusutan peralatan dimana biaya pajak yang dikeluarkan petani sebesar Rp 1.030.000 per satu tahun.Sedangkan biaya penyusutan peralatan yang dikeluarkan petani sebesar Rp.4.308.300, maka total 
biaya tetap yang dikeluarkan oleh petani responden sebesar Rp.5.338.300

Berdasarkan pendapat yang dikemukakan oleh Muhammad (2004) bahwa biaya tetap yang dimaksud dalam penelitian ini adalah biaya yang tidak habis digunakan dalam satu kali proses produksi tetapi hanya mengalami penyusutan atau disebut sebagai biaya investasi seperti pengadaan peralatan untuk menunjang keberlanjutan usaha tani lada. Untuk mengeathui besarnya penyusutan dari masing-masing peralatan yang digunakan maka akan dihitung nilai penysutan yang habis dalam satu produksi.

\section{c. Total Biaya Produksi}

Biaya total adalah jumlah biaya tetap dan biaya variabel. Setelah beberapa jenis biaya yang dikeluarkan untuk memprodksi sesuatu menentukan harga pokok dari produk yang dihasilakn. Biaya produksi adalah biaya yang dikeluarkan selama proses produksi yang meliputi biaya peralatan, upah tenaga kerja, bahan bakar. Sesuai dengan penyusutan waktu tiap periode, terdapat perbedaan biaya produksi untuk masing- masing periode ( Irmayani 2014).

Maka dapat di gambarkan seluruh biaya usaha tani, yang dikeluarkan petani responden (Suratiya 2009) untuk lebih jelasnya dapat dilihat pada tabel 4.

Tabel 4. Total Biaya Produksi Yang Dikeluarkan Petani Lada Responden Di Desa Sanglepongan Kecamatan Curio Kabupaten Enrekang

\begin{tabular}{clr}
\hline No & Jenis Biaya & Nilai $(\mathrm{Rp})$ \\
\hline 1 & biaya variabel & $\mathrm{Rp} 49.417 .000$ \\
2 & biaya tetap & $\mathrm{Rp} \mathrm{5.338.300}$ \\
\hline & & $\mathrm{Rp54.755.300}$ \\
& Jumlah & \\
\hline
\end{tabular}

Sumber Data Primer Setelah Di Olah 2020

Tabel 4 menjelaskan bahwa nilai total biaya tetap yang dikeluarkan petani lada salam satu kali proses produksi yaitu sebesar Rp. 5.338.300. dan nilai total biaya variabel satu kali proses produksi sebesar Rp49.417.000 jadi total biaya dalam satu kali produksi adalah sebesar Rp. 54.755 .300

Hal ini serupa dengan penelitian Rudi Aditia (2018) yang menyatakan bahwa biaya tetap untuk membeli alat dan perlengkapan usaha tani lada lebih kecil daripada biaya variabel hal ini disebabkan karna biaya tetap terdistribusi pada setiap periode usaha dan juga karena peralatan pendukung usaha tani dapat dipakai berulang sehingga yang di hitung adalah biaya penyusutan yang jumlahnya lebih kecil.

Berdasarkan peneltian Maria(2016) dijelaskan bahwa petani memiliki keinginan untuk menghasilkan produksi yang optimal. Sebagai salah satu cara 
menggunakan pupuk dengan tujuan untuk memenuhi kebutuhan dari tanaman kedelai itu sendiri yang nantinya akan diiringi peningkatan produksi kedelai. dan biaya variabel memiliki biaya lebih tinggi dari biaya tetap yaitu sebesar Rp.5.702.229/ha/MT dengan tingkat persentasenya adalah 79,87 persen.

\section{d. Penerimaan}

Penerimaan merupakan hasil perkalian antara produksi yang diperoleh degan harga jual pada saat penelitian. Hal ini sesuai dengan pendapat Soekartawati 1995, yang menjelaskan bahwa penerimaan usaha tani dipoeroleh dengan mengalikan total produksi dengan harga jual petani. Jumlah produksiresponden dalam usaha tani lada adalah dengan ratarata harga lada Rp 50.000 per kilogram.

Untuk mengetahui penerimaan responden dalam usaha tani lada dapat di analisa dengan rumus penerimaan yaitu:

Tabel 5.Total Penerimaan Yang Dikeluarkan Petani Lada Responden Di Desa Sanglepongan Kecamatan Curio Kabupaten

\section{Enrekang}

\begin{tabular}{clc}
\hline No & \multicolumn{1}{c}{ Uraian } & Jumlah $(\mathrm{Rp} / \mathrm{Kg})$ \\
\hline 1 & Produksi & $4084 \mathrm{Kg}$ \\
2 & Harga $/ \mathrm{Kg}$ & $\mathrm{Rp} \mathrm{50.000}$ \\
3 & Total Penerimaan & Rp 204.200.000 \\
\hline \multicolumn{3}{l}{ Sumber Data Primer Setelah Di Olah 2020 }
\end{tabular}

Berdasarkan Tabel 5 dapat diketahui harga pokok lada sebesar Rp. $50.000 / \mathrm{Kg}$ dan jumlah produksi yang dihasilkan $4084 \mathrm{Kg}$ sehingga penerimaaan responden dalam usaha tani lada desa Sanglepongan Kecamatan Curio Kabupaten Enrekang yaitu sebanyak Rp 204.200.000 per panen.

Hal ini serupa dengan penelitian Gusti Ulandari (2019) menunjukkan bahwa dalam satu kali musim panen, ratarata total produksi pada usaha tani lada adalah sebesar 95,086 Kg/1 musim panen. total penerimaan usaha tani lada denga harga Rp.12.000/kilo adalah Rp.1.141.032.00/musim. Oleh karna itu dapat disimpulkan bahwa besar kecilnya penerimaan yang diperoleh responden sangat ditentukan dari besarnya produksi dan harga lada yang dihaslkan oleh responden.Dengan besarnya penerimaan tersebut, diharpkan responden mammpu menutupi biaya produksi yang dikeluarkan dalam pengolahan usaha tani lada sehingga mampu menghasilkan pendapatan yang menguntungkan bagi responden.

Penerimaan menurut Suratiyah (2015) adalah perkalian antara produksi dengan harga jual, besarnya penerimaan yang diterima oleh petani untuk setiap rupiah yang dikeluarkan dalam kegiatan produksi usahatani dipengaruhi oleh jumlah produksi yang dihasilkan dan harga satuan produksi yang 
dihasilkan.Semakin tinggi jumlah produksi dan harga satuan produksi yang dihasilkan maka penerimaan usahatani semakin besar sebaliknya, semakin rendah jumlah produksi dan harga satuan produksi yang dihasilkan maka penerimaan usahatani semakin kecil.

\section{e. Pendapatan}

Pendapatan adalah total penerimaan dikurangi dengan total biaya. Hal ini sesuai dengan pendapat Soekartawati 1995 bahwa pendapatan atau keuntungan usahatani adalah selisi antara total penerimaan dengan semua biaya usahatani. Pendapatan petani lada responden di Desa Sanglepongan Kecamatan Curio Kabupaten Enrekang Dapat diperoleh dengan Rumus menurut Soekartawati 1995 sebagai berikut:

Tabel 6. Total Pendapatan Yang Diperoleh Petani Lada Responden Di Desa Sanglepongan Kecamatan Curio Kabupaten Enrekang

\begin{tabular}{cll}
\hline No & \multicolumn{1}{c}{ Uraian } & Jumlah( Rp) \\
\hline 1 & Total Penerimaan & Rp. 204.200 .000 \\
2 & Total Biaya & Rp. 54.755 .300 \\
\hline \multicolumn{2}{c}{ Total Pendapatan } & Rp. 149.444 .700 \\
\hline Sumber Data Primer Setelah Di Olah 2020
\end{tabular}

Angka yang diperoleh pada Tabel 6 di atas menunjukkan bahwa penerimaan yang diperoleh usaha tani lada dalam satu kali proses produksi Rp204.200.000 sedangkan total biaya yang digunakan usaha tani dalam satu kali produksi yakni sebsesar Rp54.755.300. Dengan rata-rata pendapatan yang diperoleh petani lada di desa Sanglepongan Kecamatan Curio Kabupaten Enrekang yaitu sebesar Rp149.444.700 per produksi.

Tingkat pendapatan petani berkisar Rp1.859.700 hingga Rp12.804.500 per produksi sedangkan rata- rata pendapatan petani lada di Desa Sanglepongan yaitu sebesar Rp5.900.788 per produksi. Dari hasil perhitungan rentang pendapatan petani berada di kelompok kriteria sedang karena berada kisaran Rp5.507.967 hingga Rp9.156.233.

Menurut hartono (1998) besar kecilnya pendapatan usaha tani yang diperoleh tergantung dari beberapa faktor yang mempengaruhinya seperti luas lahan,jumlah pohon,tingkat produksi dan identitas petani.

Nurhapsa (2015), pendapatan atau keuntunganpetani dapat diketahui denganmengurangi penerimaan dengan totalbiaya yang dikeluarkan per musim tanam.Adapun pendapatan yang diperolehpetani responden di KecamatanAnggeraja adalah Rp 45.167.760/ha.Berbeda dengan hasil penelitian yangdilakukan oleh Setyono dan Suradai(2006) menunjukkan bahwa petanibawang merah di Kabupaten Bantul dapatmencapai keuntungan sebesar Rp84.620.000/ha. 
Hasil penelitian Bahari (2019) bahwa rata- rata penerimaan pada usaha tani lada yaitu Rp. 34.576.727/musim tanam dengan rata-rata biaya yaitu sebesar Rp.27.161.576/ musim tanam sedangkan pendapatn yang diperoleh Rp. 4.265.813/ musim tanam olehkarena itu biaya yang dikeluarkan sebanding dengan penerimaan yang diperoleh. Pendapatan diterima petani merupakan hasil dari usaha yang telah digelutinya dengan menggunakan beberapa faktor produksi .

\section{Analisis Kelayakan Usaha Tani Lada}

Soeharto (1997) bahwa B/C Ratio merupakan metode yang dilakukan untuk melihat berapa manfaat yang diterima oleh proyek untuk satu satuan matauang (dalam hal rupiah) yang dikeluarkan. B/C Ratio adalah suatu rasio yang membandingkan antara benefit atau pendapatan dari suatu usaha dengan biaya yang dikeluarkan. Sedangkan menurut Rahardi dan Hartono (2003) analisis B/C Ratio adalah perbandingan antara tingkat keuntungan atau pendapatan yang diperoleh dengan total biaya yang dikeluarkan. Suatu usaha dikatakan layak dan memberi manfaat.

Menurut Kasmir dan Jakpar (2003) studi kelayakan pada hakikatnya adalah suatu kegiatan yang mempelajari secara mendalam tentang suatu kegiatan atau usaha atau bisnis yang akan dijalankan, dalam rangka menentukan layak atau tidak usaha tersebut dijalankan. Kelayakan usaha tani lada yang dilakukan oleh petani responden di Desa Sanglepongan Kecamatan Curio Kabupaten Enrekang dapat diketahui dengan menggunakan rumus B/C Rasio.

Tabel 7. Nilai B/C Rasio Petani lada Di Desa Sanglepongan Kecamatan Curio Kabupaten Enrekang

\begin{tabular}{|c|c|c|c|}
\hline No & $\begin{array}{c}\text { Pendapatan }(\pi) \\
(\mathrm{Rp})\end{array}$ & $\begin{array}{c}\text { Total Biaya } \\
\text { (TC) } \\
\text { (Rp) }\end{array}$ & $\begin{array}{l}\text { Nilai } \\
\text { B/C } \\
\text { Rasio } \\
(\pi / \mathrm{TC})\end{array}$ \\
\hline 1 & 149.444 .700 & 54.755 .300 & 2.72 \\
\hline
\end{tabular}

Diketahui pada Tabel 7 bahwa pendapatanpetani lada di desa sanglepongan kecamatan curio kabupaten enrekang adalah sebesar Rp149.444.700 per produksi dan total biaya yang dikeluarkan petani lada sebesar $\mathrm{Rp}$ 54.755.300 per produksi . Maka dengan demiikian nilai benefit cost ratio (B/Cratio) adalah sebesar 2,72 menunjukkan bahwa $\mathrm{B} / \mathrm{C}>1$ berarti usaha layak untuk dijalankan. Atau denga kata lain pendapatan lebih besar dari total biaya yang dikeluarkan maka usaha ladadi Desa Sanglepongan di Kecamatan Curio Kabupaten Enrekang layak untuk dijalankan. 
Hasil penelitian sebelumnya oleh Rahim dan Hastuti, (2007:168-169) bahwa analisis B/C (Benefit Cost Ratio) merupakan perbandingan (ratio atau nisbah) antar manfaat (benefit) dan biaya (cost). Pada analisis $B / C$ ratio dipentingkan besarnya manfaat. Selain analisis $B / C$ ratio dapat digunakan untuk membandingkan 2 (dua) atau lebih usaha. Jika hasil $B / C$ ratio lebih besar dari satu maka usaha tersebut menguntungkan (tambahan manfaat/penerimaan lebih besar dari tambahan biaya). Serta jika hasil $B / C$ Ratio kurang dari satu maka usaha tersebut mengalami kerugian (tambahan biaya lebih besar dari tambahan penerimaan). Dan apabila hasil B/C Ratio sama dengan satu, maka usahatani tersebut inpas (tambahan penerimaan sama dengan tambahan biaya).

\section{KESIMPULAN DAN SARAN}

Total pendapatan lada di daerah sanglepongan adalah Rp149.444.700/ produksi. pendapatan petani cukup besar untuk digunakan menutupi kegutuhan hidup dan menunjang keuangan rumah tangga petani dikala tepuruknya harga komoditi pertanian di desa sanglepongan Kecamatan Curio Kabupaten Enrekang.Nilai benefit cost ratio (B/Cratio) adalah sebesar 2,72 menunjukkan bahwa $\mathrm{B} / \mathrm{C}>1$ berarti usaha layak untuk dijalankan. Atau denga kata lain pendapatan lebih besar dari total biaya yang dikeluarkan maka usaha ladadi desa sanglepongan di Kecamatan Curio Kabupaten Enekang layak untuk di jalanka

Untuk meningkatkan pendapatan petani lada sebaiknya jumlah luas lahan yang diusahakan ditambah dan meminimkan jumlah modal kerja yang digunakAN.Diharapkan dari pemerintah untuk mengadakan kebijakan harga atau menetapkan harga dimana kebijaksanaan ini diperlukan untuk menjaga agar harga pada saat panen tidak terjadi fluktuasi, sehingga petani petani lada bersemangat dalam mengolah lahan pertanian yang mengakibat meningkatnya taraf hidup petani. Jika tingkat kesejahteraan petani meningkat tidak menuntut kemungkinan akan diikuti oleh pembangunan ekonomi yang lebih baik dan tingkat kemiskinan berkurang.

\section{DAFTAR PUSTAKA}

Ananta, 1999.Penelitian Tentang Sektor Informal.Jurnal ekonomi UGM.Yogyakarta

Irmayani, Yusuf. S, Nispar.M, 2014. Analisis Kelayakan Usaha Budidaya Rumput Laut Di Desa Mallaroso Kecamatan Bangkala Kabupaten Jeneponto.Jurnal bisnis perikanan. 
Kasmir dan Jakfar, 2003. Study Kelayakan Bisnis. Prenada Media. Jakarta Timur.

Kieso, Donald E., et al. 2010. Akuntansi Intermediate. Jakarta: Erlangga.

Mubyrto. 1994. pengantar ekonomi pertanian. LP3ES.Jakarta

Mubyarto (1989), Pengantar Ekonomi Pertanian, Jakarta : Edisi Ke-tiga, LP3S

Mubyarto 1995.Pengantar ekonomi pertanian. Jakarta: Edisi KeTiga.LP3S.

Masri Singarimbun \& Sofian Effendi.1998.Metode Penelitian Survei. Jakarta:LP3ES

Nuryanti, D.M. dan N.N. Kasim. 2017. Analisis Perbedaan Usaha Mikro Sebelum Dan Sesudah Menerima Bantuan Kredit Program Nasional Pemberdayaan Masyarakat (PNPM) Mandiri Pedesaan. TESIS. Fakultas Ekonomi Sebelas Maret, Surakarta.

Plantamor Situs Dunia Tumbuhan.(2016). Amaranthus hybridus, Amaranthus tricolor, Alternanthera amoena Voss. http://plantamor.com/. Diakses pada tanggal 14 Mei 2016.

Rahadi dan Hartono. 2003, Agribisnis Peternakan. Ed Rev, Penebar Swadaya. Jakarta

Rahardjo, P. 2001. Teori Ekonomi Makro Suatu Pengantar. UI Press. Jakarta

Salman, (2013). Akuntansi Biaya. Cetakan Pratama. Jakarta: Akademia Pratama.

Sarpian, T. 2004. Lada: Mempercepat Berbuah, Meningkatkan Produksi, Memperpanjang Umur. Penebar Swadaya. Jakarta

Soekartawi, dkk 1986. Ilmu Usahatani. Universitas indonesia, UiPress,Salemba, Jakarta

Soekartawi, dkk 1995. Analisis Usahatani. Jakarta: UI Press.

Soekartawi, dkk 2002. Analisis Usahatani. Jakarta: Universitas Indonesia.
Soekartawi, dkk 2006. Analisis usahatani. Jakarta. Universitas indonesia.

Sehrawat, M.S and J.S Narang.(2001). Production Management, Nai Sarak, Dhanpahat RAI Co.

Sukirno, 2004.Pengantar Teori Makroekonomi. Jakarta: PT Raja Grafindo Persada.

Soedjarwanto dan Riswan.1994. Penyerapan Tenaga Kerja Pada Industri Batubata di Kabupaten Dati II Banyumas. Laporan Hasil Penelitian Fakultas Ekonomi Unsoed. Purwokerto. 
